\title{
Использование ферментных препаратов и лецитина для улучшения использования питательных веществ рациона цыплятами-бройлерами
}

Калоев Б.С., доктор сельскохозяйственных наук, зав. кафедрой кормления, разведения и генетики сельскохозяйственных животньх ФГБОУ ВО «Горский государственный аграрный университөт», г. Владикавказ

Ибрагимов М.О., кандидат сельскохозяйственньх наук, доцент кафедры технологии производства и переработки сельскохозяйственной продукции

\begin{abstract}
Аннотация: Приведены результаты научно-хозяйственного опыта по изучению влияния смеси дбух ферментных препаратов (один из которых содержал ксиланазу, бета-глюканазу, маннаназу и иеллюлазу, а другой - фитазу) и лецитина на переваримость и использование питательных веществ рациона иыплятамибройлерами. Oпыт проводился на 4 группах бройлеров кросса Ross-308 (одна контрольная и 3 опытные) $c$ суточного до 45-дневного возраста. Бройлерам всех групп в качестве основного рациона скармливали полнорационные комбикорма, приготовленные на основе кукурузы, ячменя, пшеницы и подсолнечного жмыха. Поголовью I, 2 и 3 опытных групп к основному рациону добавляли, соответственно группам, смесь дбух ферментных препаратов (100 2/m); лецитин (10 2/к2); обе добабки 6 тех же дозах. Были определены коэффициенты переваримости питательных веществ, баланс азота, кальция и фосфора, свидетельствующие о положительном влиянии изучаемых препаратов на эффективность пищеварения. Экзогенные ферменты и лецитин активизировали собственную ферментную систему иыплят, ито проявилось 6 достоверном ( $P<0,05-0,001)$ повышении по сравнению $c$ контролем коэффициентов переваримости основных питательных веществ: сырого протеина - на 3,23-4,08\%, сырой клетчатки - на 2,572,70\%, БЭВ - на 4,36-4,84\%, сырого жира - на 2,67-3,25\%. Отмечено также достоверное положительное влияние изучаемых добабок на баланс азота и фосфора; 6 случае кальция достоверный эффект наблюдался только при совместном использовании обеих добавок.
\end{abstract}

Ключебые слоса: цыплята-бройлеры, ферментные препараты, лецитин, коэффициенты переваримости питательных вещестө, баланс, азот, кальций, фосфор.

Введение. Современная птицеводческая отрасль, использующая высокопродуктивные кроссы птицы, не может обойтись без включения в их рационы биологически активных препаратов, улучшающих использование питательных веществ корма. Связано это, в первую очередь, С наличием в кормовых компонентах, из которых готовятся комбикорма, широкого спектра труднопереваримых веществ, В частности, некрахмалистых полисахаридов, определенной части белков и липидов. Для их расщепления и более полного использо- вания в рацион птицы включают комплексные ферментные препараты, также способные активизировать еe собственные ферментные системы [1-4].

Улучшение использования питательных веществ рациона за счет использования ферментных препаратов напрямую отражается на продуктивных качествах птицы, что, в итоге, способствует повышению эффективности производства продукции птицеводства [5-9].

В последнее время обращается более пристальное внимание на сочетаемость различных биологи- чески активных препаратов, используемых в кормлении птицы. Среди таких препаратов - фосфолипидные препараты и, в частности, лецитин, эффективность включения которого в рационы птицы отмечают многие авторы [10-12].

Исходя из вышеизложенного, цель исследований заключалась в изучении влияния ферментных препаратов и лецитина, вводимых в комбикорм растительного типа по отдельности и вместе, на переваримость и использование питательных веществ рациона цыплятами-бройлерами. 
Таблица 1. Cхема опыта

Tpynna

Особенности кормления

Полнорационные комбикорма для бройлеров «Старт», «Рост»,

Контрольная «Финиш» на основе кукурузы, ячменя, пшеницы, подсолнечного жмыха (OP - основной рацион)

1 опытная

2 опытная

3 опытная OP + лецитин из расчета $10 \mathrm{r} / \mathrm{kr}$ корма

OP + смесь 2 ферментных препаратов $(100 \mathrm{r} / \mathrm{T})+$ лецитин $(10 \mathrm{r} / \mathrm{kr})$

\section{Материал и методика иссле-}

дований. Научно-хозяйственный опыт был проведен в условиях племенного репродуктора «АчхойМартановский» Чеченской Республики по схеме, представленной в табл. 1.

Первый ферментный препарат представлял собой комплексное средство для смешанных рационов, полученное путем бактериального синтеза, в составе которого 4 активных фермента: ксиланаза - не менее 12000 К-ед./г, бетаглюканаза - не менее 4000 г-ед./г, маннаназа - не менее 100 М-ед./г, целлюлаза - не менее 2000 Ц-ед./г; наполнитель - кукурузный крахмал. Второй ферментный препарат - бактериальная фитаза (миоинозитол-гексафосфат-фосфогидролаза) с минимальной активностью сухого препарата 5000 Ф-ед./r; наполнитель - кукурузный крахмал.

Из суточных цыплят кросса Ross-308 по принципу аналогов было сформировано 4 группы по 100 голов в каждой. Кормление подопытного поголовья осуществлялось полнорационными комбикормами, приготовленными на основе кукурузы, ячменя, пшеницы, подсолнечного жмыха местного производства. Разница в условиях кормления между контрольной и 3 опытными группами заключалась в скармливании птице опытных групп изучаемых ферментных препаратов и лецитина согласно схеме опыта (табл. 1). Нормы скармливания ферментных препаратов (100 г/т корма) и лецитина (10 r/кr корма) были определены предварительно, в предыдущих научнохозяйственных опытах.

Для определения переваримости питательных веществ кормов и их усвояемости бройлерами был проведен физиологический опыт по методике М.И. Дьякова (1959) на 5 головах, типичных для своей группы, по результатам которого определены коэффициенты переваримости, а также баланс азота, кальция и фосфора по общепринятым в зоотехнии методикам.

Результаты исследований и их обсуждение. Ранее полученные показатели ферментативной активности разных групп ферментов в желудочно-кишечном тракте подопытной птицы могут служить основанием для подтверждения результатов исследований по определению переваримости питательных веществ. Степень влияния изучаемых препаратов на переваримость и использование бройлерами основных питательных веществ устанавливалась путем определения коэффициентов их переваримости и баланса азота.

Ферментные препараты и лецитин, как вместе, так и по отдельности, оказали достоверное положительное влияние на переваримость основных питательных веществ рациона бройлерами опытных групп (табл. 2).

Стимулирующее действие изучаемых ферментных препаратов и лецитина на пищеварение и оптимизация ими углеводного и протеинового обмена проявились в достоверном повышении по сравнению с контролем в 1,2 и особенно 3 опытных группах коэффициентов переваримости сырого протеина, сырой клетчатки и БЭВ. Улучшение соотношения ненасыщенных и насыщенных жирных кислот в рационе благодаря использованию лецитина оптимизировало липидный обмен, что выразилось В достоверном повышении коэффициентов переваримости сырого жира по сравнению с контролем на 2,67\% при отдельном использовании лецитина и на 3,25\% - при его совместном использовании с ферментными препаратами $(P<0,01)$.

Лучшее использование отдельных питательных веществ организмом бройлеров опытных групп соответственно повышает использование органического вещества рациона в целом. Ввод в рацион лецитина достоверно повысило переваримость органического
Таблица 2. Коэффициенты переваримости питательных веществ, \% (n=5)

\begin{tabular}{|c|c|c|c|c|}
\hline \multirow[t]{2}{*}{ Показатель } & \multicolumn{4}{|c|}{ Tpynna } \\
\hline & контрольная & 1 опыпная & 2 опытная & 3 опытная \\
\hline $\begin{array}{l}\text { Органическое } \\
\text { вещество }\end{array}$ & & & & \\
\hline Сырой протеин & $84,77 \pm 0,52$ & $88,81 \pm 0,50^{* * *}$ & $88,32 \pm 0,41^{\text {*** }}$ & $88,32 \pm 0,41^{\text {t**}}$ \\
\hline Сырой жир & $78,67 \pm 0,38$ & $80,25 \pm 0,42^{*}$ & $81,34 \pm 0,51^{* *}$ & $81,34 \pm 0,51^{* *}$ \\
\hline Сырая клетчатка & $18,28 \pm 0,33$ & $20,85 \pm 0,38^{\star * *}$ & $20,32 \pm 0,22^{\star \star \star}$ & $20,32 \pm 0,22^{* * *}$ \\
\hline БЭВ & $85,27 \pm 0,61$ & $89,63 \pm 0,61^{\star * \star}$ & $88,91 \pm 0,52^{\star *}$ & $88,91 \pm 0,52^{* *}$ \\
\hline
\end{tabular}

Различия с контролем достоверны при: *p<0,05; **p<0,01; ***p<0,001. 


\begin{tabular}{|c|c|c|c|c|}
\hline \multirow[t]{2}{*}{ Показатель } & \multicolumn{4}{|c|}{ Tpynna } \\
\hline & контрольная & 1 опыпная & 2 опытная & 3 опытная \\
\hline Принято с кормом & $3,511 \pm 0,045$ & $3,510 \pm 0,056$ & $3,509 \pm 0,044$ & $3,512 \pm 0,058$ \\
\hline Выделено с калом & $0,528 \pm 0,041$ & $0,387 \pm 0,040^{\star}$ & $0,425 \pm 0,022^{\star}$ & $0,386 \pm 0,034^{*}$ \\
\hline Выделено с мочой & $1,090 \pm 0,057$ & $1,180 \pm 0,046$ & $1,153 \pm 0,065$ & $1,174 \pm 0,077$ \\
\hline $\begin{array}{l}\text { Отложено в } \\
\text { организме, г }\end{array}$ & $1,893 \pm 0,011$ & $1,943 \pm 0,021^{*}$ & $1,931 \pm 0,013^{*}$ & $1,952 \pm 0,019^{*}$ \\
\hline Использовано, \% & 53,44 & 55,36 & 55,03 & 55,58 \\
\hline
\end{tabular}

Различия с контролем достоверны при: *p<0,05.

вещества рациона на $2,84 \%$, смеси ферментных препаратов - на 3,23\%, а их совместный ввод - на 4,05\% ( $\mathrm{P}<0,001)$.

Таким образом, мы можем говорить о вероятности активизации процессов расщепления и всасывания органических веществ корма благодаря включению испытуемых препаратов в рацион бройлеров.

Известно, что в основе высоких продуктивных показателей лежит оптимизация обменных процессов в организме животных и птицы. Для характеристики белкового обмена определены баланс и использование азота (табл. 3), а для характеристики минерального обмена - балансы кальция и фосфора (табл. 4 и 5). Эти показатели лежат в основе роста откармливаемой птицы.

Исходя из того, что вся подопытная птица выращивалась по одной технологии и получала комбикорма со сбалансированной питательной ценностью, количество поступившего с кормом азота во всех группах было на уровне 3,509-3,512 г, т.е. практически одинаковым.

Разделение азотистых веществ кала и мочи в помете бройлеров показало, что в опытных группах количество не усвоенного и выделенного с калом азота было достоверно меньше, чем в контрольной группе. Меньше всего азота содержалось в кале птицы 1 и 3 опытных групп, чуть больше - в кале птицы 2 опытной группы и больше всего - в кале птицы контрольной группы; различия опытных групп с контрольной по этому показателю составили 0,103-0,142 г.

Определение содержания азота в моче, наоборот, показало повышение его количества в опытных группах, что говорит о более тесном вовлечении азота в белковый обмен цыплят, получавших с рационом ферментные препараты и лецитин. Однако разница с контрольной группой была недостоверной. Эти показатели согласуются с результатами определения коэффициента переваримости протеина.

В результате количество отложенного в организме азота у бройлеров опытных групп было достоверно выше в сравнении с контрольной группой на 0,038-0,059 г $(\mathrm{P}<0,05)$, а использование азота
Различия с контролем достоверны при: *р<0,05. выше на 1,59-2,14\%.

В основе высоких и стабильных приростов живой массы лежит не только хороший белковый обмен, но и минеральный. Хорошее развитие костной ткани предопределяет интенсивный прирост мышечной ткани. Кальций и фосфор являются основными показателями минерального обмена в организме животных и птицы, поэтому у подопытных бройлеров был изучен баланс этих элементов.

Известно, что фитаты, в повышенном количестве содержащиеся в злаковых зерновых культурах, являющихся основными компонентами комбикормов СевероКавказского региона, препятствуют эффективному усвоению кальция и фосфора организмом сельскохозяйственной птицы $[2,4]$.

Мы отмечали, что один из изучаемых ферментных препаратов имеет в своем составе фитазу, которая как раз способствует разрушению фитатов, повышая тем самым доступность и использование кальция и фосфора организмом бройлеров опытных групп. Этот эффект особенно ярко проявился при совместном использовании в рационе ферментных препаратов и лецити-

\begin{tabular}{|c|c|c|c|c|}
\hline \multirow[t]{2}{*}{ Показатель } & \multicolumn{4}{|c|}{ Tpynna } \\
\hline & контрольная & 1 опытная & 2 опытная & 3 опытная \\
\hline Принято с кормом & $1,368 \pm 0,012$ & $1,366 \pm 0,015$ & $1,368 \pm 0,018$ & $1,370 \pm 0,013$ \\
\hline Выделено с пометом & $0,509 \pm 0,010$ & $0,472 \pm 0,013$ & $0,493 \pm 0,011$ & $0,471 \pm 0,010^{*}$ \\
\hline \multicolumn{5}{|l|}{ Отложено в } \\
\hline организме & $0,859 \pm 0,011$ & $0,894 \pm 0,012$ & $0,875 \pm 0,012$ & $0,899 \pm 0,009^{*}$ \\
\hline Использовано, \% & 62,79 & 65,45 & 63,96 & 65,62 \\
\hline
\end{tabular}

\begin{tabular}{|c|c|c|c|c|}
\hline \multirow[t]{2}{*}{ Показатель } & \multicolumn{4}{|c|}{ Tpynna } \\
\hline & контрольная & 1 опытная & 2 опытная & 3 опытная \\
\hline Принято с кормом & $1,019 \pm 0,017$ & $1,023 \pm 0,014$ & $1,018 \pm 0,012$ & $1,021 \pm 0,015$ \\
\hline Выделено с пометом & $0,510 \pm 0,015$ & $0,451 \pm 0,014^{*}$ & $0,459 \pm 0,012^{*}$ & $0,450 \pm 0,013^{\star}$ \\
\hline Отложено в организме & $0,509 \pm 0,015$ & $0,572 \pm 0,015^{\star}$ & $0,559 \pm 0,014^{*}$ & $0,577 \pm 0,017$ \\
\hline Использовано, \% & 49,95 & 55,91 & 54,91 & 56,51 \\
\hline
\end{tabular}


на, который, благодаря усилению проницаемости клеточных мембран, повышает эффективность всасывания кальция и фосфора в кишечнике.

Например, при изучении баланса кальция (табл. 4) установлено, что только при совместном использовании ферментных препаратов и лецитина в 3 опытной группе повышение отложения кальция в организме бройлеров по сравнению с контролем было достоверным (на 4,66\%, Р<0,05); при этом его использование от принятого количества также увеличилось на 2,83\%. Близкие к этим показателям результаты, хотя и недостоверные, зафиксированы и в 1 опытной группе, получавшей только ферменты. При отдельном использовании лецитина эффект был незначительным.

Более существенное влияние изучаемые биологически активные препараты оказали на баланс фосфора (табл. 5). Так, использование в рационе бройлеров смеси ферментных препаратов с фитазой в составе, в результате разрушения фитиновой кислоты в зерновых компонентах рациона, позволило повысить отложение в теле и использование фосфора птицей 1 опытной группы по сравнению с контролем соответственно на 0,063 г $(P<0,05)$ и $5,96 \%$.

Фосфолипид лецитин, обладая повышенным содержанием метаболически активных ненасыщенных жирных кислот, вероятно, усилил фосфорный обмен, повысив всасываемость этого элемента в кишечнике. Благодаря этому отложение фосфора в организме бройлеров 2 опытной группы достоверно повысилось по сравнению с контролем на 0,050 г $(\mathbf{P}<0,05)$, a ero использование - на 4,96\%.
Совместное использование ферментных препаратов с лецитином оказало более значительный эффект. Отложение фосфора в теле цыплят 3 опытной группы достоверно увеличилось по сравнению с контролем на 0,068 г $(P<0,05)$, а его использование - на 6,56\%.

Заключение. Полученные в исследовании данные позволяют сделать заключение, что комбикорма, приготовленные на основе кукурузы, ячменя, пшеницы, подсолнечного жмыха, обогащенные ксиланазой, бета-глюканазой, маннаназой, целлюлазой и фитазой, в сочетании с лецитином (10 г/кг), достоверно улучшают использование бройлерами питательных и минеральных веществ корма, что подтверждается повышением коэффициентов переваримости основных питательных веществ и улучшением баланса азота, кальция и фосфора.

\section{Литература}

1. Анчиков В. Эффективность применения ферментов в птицеводстве / В. Анчиков, С. Кислюк // Комбикорма. 1999. - №2. - С.30-31.

2. Егоров И.А. Роль ферментных препаратов в повышении эффективности комбикормов, содержащих трудногидролизуемые компоненты / И.А. Егоров, А.В. Егорова // Птицефабрика. - 2009. №4. - C. 16-38.

3. Калоев Б.С. Переваримость питательных веществ у бройлеров, получавших ферментные препараты / Б.С. Калоев, М.о. Ибрагимов // Научная жизнь. 2017. - №4. - C. 58-66

4. Нуфер А. Мультиэнзимный комплекс Санзайм и фитаза Санфайз - усилители питательной ценности кормов // Птицеводство. - 2010 . - №7. - С. 30-31.

5. Лисицына А. Ферментные препараты снижают стоимость корма / А. Лисицына, В. Меньшиков // Птицеводство. -
2000. - №5. - C. 55.

6. Мальцева Н.А. Использование ферментного препарата Санзайм в кормлении мясных цыплят / Н.A. Мальцева, Е.И. Амиранашвили // Птахівництво. Харків. - 2012. - Вып. 68. - С. 288-296.

7. Калоев Б.С. Ферментные препараты в кормлении бройлеров / Б.С. Калоев, М.о. Ибрагимов // Птицеводство. 2017. - №8. - С. 29-32.

8. Кононенко С.И. Мультиэнзимная композиция в составе полнорационного комбикорма // Изв. Горского ГАУ. 2013. - T. 50, №1. - C. 138-141.

9. Kaloev B.S. Enzyme preparations and qualitative indicators of eggs / B.S. Kaloev, M.O. Ibragimov, F.M. Kulova, V.V. Nogaeva, L.Kh. Albegova, A.T. Kokoeva // Res. J. Pharm. Biol. Chem. Sci. - 2019. V. 10, No 2. - P. 241-247.

10. Лисовая Е.В. Анализ ассортимента лецитинов, представленных на российском рынке / Е.В. Лисовая, Е.П. Викторова, В.В. Лисовой // Технологии пищевой и перерабатывающей промышленности АПК - продукты здорового питания. - 2019. - №2(28). - С. 51-55.

11. Каиров А.В. Переваримость и усвояемость питательных веществ при включении в рацион мясной птицы биологически активных препаратов для детоксикации Т-2 токсина / А.В. Каиров, Р.Б. Темираев, М.Н. Мамукаев, И.И. Кцоева, М.К. Кожоков [и Ар.] // Изв. Горского ГАУ. - 2019. - Т. 56, №4. - С. 108-113.

12. Темираев Р.Б. Морфологический и биохимический состав крови мясной птицы при применении в рационах биологически активных препаратов / Р.Б. Темираев, А.В. Каиров, Ф.Н. Цогоева, М.К Кожоков, С.Ф. Ламартон, Е.А. Курбанова //Изв. Горского ГАУ. - 2019. - Т. 56, №1. - C. 91-97.

Для контакта савторами: Калоев Борис Сергеевич E-mail: bkaloev@yandex.ru Ибрагимов Муса Окуевич E-mail: agrofak.chgu@yandex.ru 
The Effects of a Mixture of Exogenous Enzymes and Lecithin on the Digestibility of Dietary Nutrients in Broilers

\author{
Kaloyev B.S. ', Ibragimov M.0.2 \\ ${ }^{1}$ Gorsky State Agrarian University (Vladikavkaz); ${ }^{2}$ Chechen State University (Grozny)
}

Summary: The effects of a mixture of two enzyme preparations (contained the activities as follows: 1 - xylanase, betaglucanase, mannanase, cellulase; 2 - phytase) and lecithin in vegetable diets on the digestibility and retention of dietary nutrients was studied on 4 treatments of Ross-308 broilers (100 birds per treatment, 1-45 days of age). Control treatment was fed vegetable diet (corn, barley, wheat, sunflower cake) without additives; diets for three other treatments were supplemented with the mixture of enzymes (100 ppm of total mixture); lecithin $(10 \mathrm{~g} / \mathrm{kg}$ of feed); both additives in the same doses. The coefficients of digestibility of basic nutrients and balances of nitrogen, calcium, and phosphorus were determined on 5 birds per treatment. Exogenous enzymes and lecithin were found to activate exogenous enzymatic digestive system in broilers resulting in the significant $(P<0.05-0.001)$ increases in the digestibility of crude protein (by 3.23-4.08\%), crude fiber (by 2.57-2.70\%), NFE (by 4.36-4.84\%), crude fat (by 2.67-3.25\%). The significant improvements $(P<0.05)$ were found in the retention of nitrogen and phosphorus with both additives and their combination; for the retention of calcium the effect was significant only with the combination of enzymes and lecithin.

Key words; broiler chicks, enzyme preparations, lecithin, digestibility coefficients, balance, nitrogen, calcium, phosphorus.

OTPACIEB:IE HOBOCTИ

\title{
В России упали иены на индейку
}

По данным "Мониторинга цен на мясо птицы в России и за рубежом", подготовленного ИАА «ИМИТ», на $39-и ̆$ неделе 2020 года миробые цены на бройлера изменились незначительно и снизились 6 среднем на 0,4\% до $\$ 1,56$ за к2. По срабнению с прошлым месяцем бройлер подорожал 6 среднем на 2,6\%. в Бразилии за месяи туика бройлера подорожала $21,1 \%$ на фоне устойчивого спроса на внешних рынках и высокой конкурентоспособностью продукта бнутри страны.

В России цена на туику ЦБ в долларовом быражении за неделю снизилась на $1,9 \%$ до $\$ 1,36$ за к2, а по сравнению с прошлым месяцем стала ниже на 2,3\%.

На 39-й неделе 2020 года б России цены на куриное мясо 6 среднем выросли на 0,04\%, а по сравнению с прошлым месяцем стали ниже на 0,9\%. Стоимость куриной разделки за неделю выросла на 0,1\%, а иены на субпродукты стали выше на 0,4\%.

По состоянию на 21 сентября 2020 года установились следующие средние цены на куриное мясо российского производства: тушка ЦБ (ГОСТ) - 103,1 руб/к2, суповые куры -52,1 руб/к2, бедро- 124,6 ру6/к2, 20лень - 131,7 руб/кг, грудка - 160,4 руб/к2, крыло-142,8 руб/к2, окорочка - 120,1 руб/к2, филе грудки - 166,9 руб/к2, фари 67,0 py6/k2.

Что касается мяса индейки, то на 39-й неделе 6 США цены на туику индейки укрепились на 2,9\% до $\$ 2,52$ за к2. За месяц американская индейка стала дороже на 6,0\%.

В России цена на туики индейки отечественного произбодства (6 долларовом выражении) снизилась на 4,5\% за неделю до $\$ 2,76$ за к2, а за месяц индейка подешевела на 7,9\%.

По состоянию на 21 сентября 2020 года общий уровень цен на мясо индейки отечественного произбодства за неделю снизился на 0,6\%, а по сравнению прошлым месяцем стал ниже на 2,9\%. Цены на разделку за неделю упали на 10,9\%, а за месяина 4,8\%. 